\title{
The Reaction of some Maize Hybrids, Created at ARDS TURDA, to Fusarium spp. Infection
}

\author{
Laura ŞOPTEREAN ${ }^{1,2}$, Loredana SUCIU ${ }^{1,2}$, Ana-Maria VĂLEAN ${ }^{1,2}$, Felicia MUREŞANU ${ }^{1}$, Carmen PUIA ${ }^{2 *}$ \\ ${ }^{1}$ Agricultural Research \& Development Station Turda, Agriculturii street, No.27, 401100, Turda, \\ Romania \\ ${ }^{2}$ University of Agricultural Sciences and Veterinary Medicine, Faculty of Agriculture, 3-5, Mănăştur \\ steet, Romania \\ *Corresponding author: carmen.puia@yahoo.com
}

Bulletin USAMV series Agriculture 74(1)/2017

Print ISSN 1843-5246; Electronic ISSN 1843-5386

DOI 10.15835/buasvmcn-agr: 12658

\begin{abstract}
The most important disease of maize in Romania are stalk and ear rot, which caused yield losses in average of $20 \%$. The resistant hibrids represent one of the most efficient solution for reducing the field loses caused by Fusarium spp. on the maize (Nagy et al., 2006). Diseases caused by Fusarium spp. can affect the yield and grain quality of maize because of contamination with numerous mycotoxins produced by these fungi (Czembor et al., 2015). The purpose of this paper was to know more about the reaction of different maize hybrids to Fusarium and the evaluating the effect of ear rot on the yield ability and mycotoxins accumulation. The experiments carried out at ARDS Turda, during four years (2012-2015). The biological material was represented by 8 hybrids, from different maturity groups, tested in two infection conditions with Fusarium spp. (natural and artificial infections). The temperature and rainfalls of the four years of experiments corresponding to the vegetation of maize (aprilseptember) are influenced favourably the pathogenesis of stalk and ear rot caused by Fusarium spp. and a good discrimination of the resistance reaction of genotypes. Fusarium ear rot has significantly affected production capacity and chemical composition of corn hybrids tested. In conditions of artificial infection with Fusarium spp. was a decrease in the content of starch, fat and increased protein content compared with artificially inoculated variants. The quantity of fumonizin B1+B2 has reached to $5630 \mu \mathrm{g} / \mathrm{kg}$ in conditions of artificial infection. There are negative correlations between production capacity and degree of attack of fusarium ear rot; depending on the reacting genotypes tested increasing disease causes production decrease. The response of maize hybrids to Fusarium infection is influenced by infection and climatic conditions. These factors affect production both in terms of quantity and quality and accumulation of mycotoxins.
\end{abstract}

Keywords: Fusarium, maize, mycotoxin, quality, fumonisin

\section{INTRODUCTION}

Maize (Zea mays L.) plays an important role throughout the world. In 2011, the worldwide harvested area was 170.4 million hectares with a total production of 883 million tons (FAOSTAT, 2013). Maize is used as a staple food for more than 1.2 billion people (IITA, 2009) as well as for livestock feed and biogas production. However, maize is also known as one of the major host plants of Fusarium species. Fusarium infections not only reduce yield, but also lead to mycotoxin production in the grain and thereby contamination of food and feed products. These secondary metabolites of Fusarium are harmful to both humans and animals. Mycotoxins can cause a variety of toxic symptoms in humans and animals, ranging from gastroenteritis to cancer. The most important diseases are red ear rot (or Gibberella ear rot) and pink ear rot (also called Fusarium ear rot). Red ear rot is caused by Fusarium graminearum and Fusarium culmorum, whereas pink ear rot is caused by Fusarium verticillioides, Fusarium proliferatum and Fusarium subglutinans (Czembor, 2015; Loffler et al. 2010). In red ear rot, infection starts 
Tab. 1. The characteristics of corn hybrids to created at ARDS Turda

\begin{tabular}{ccccccccc}
\hline Specification & $\begin{array}{c}\text { TURDA } \\
145\end{array}$ & $\begin{array}{c}\text { TURDA } \\
165\end{array}$ & $\begin{array}{c}\text { TURDA } \\
200\end{array}$ & $\begin{array}{c}\text { TURDA } \\
201\end{array}$ & $\begin{array}{c}\text { TURDA } \\
\text { FAVORIT }\end{array}$ & $\begin{array}{c}\text { TURDA } \\
\text { STAR }\end{array}$ & $\begin{array}{c}\text { TURDA M0LD } \\
188\end{array}$ & $\begin{array}{c}\text { TURDA } \\
\text { SU 182 }\end{array}$ \\
\hline $\begin{array}{c}\text { The type of } \\
\text { hybrid }\end{array}$ & trilinear & trilinear & double & trilinear & simple & trilinear & trilinear & simple \\
\hline FAO & $\begin{array}{c}250 \\
\text { early }\end{array}$ & $\begin{array}{c}270 \\
\text { early }\end{array}$ & $\begin{array}{c}290 \\
\text { early }\end{array}$ & $\begin{array}{c}340 \\
\text { mid-early }\end{array}$ & $\begin{array}{c}380 \\
\text { mid-early }\end{array}$ & $\begin{array}{c}370 \\
\text { mid-early }\end{array}$ & $\begin{array}{c}290 \\
\text { early }\end{array}$ & $\begin{array}{c}290 \\
\text { early }\end{array}$ \\
\hline The grain & dentate & dentate & dentate & dentate & mid-dentate mid-glassy & dentate & dentate \\
\hline
\end{tabular}

at the tip of the ear just after female flowering and moves toward the base. Typically the husks are also infected and fuse with the ear. In pink ear rot, infection tends to be more uniform, with no real concentration at the tip (Czembor, 2015).

The accumulation of a mycelia mass of fungi of the genus Fusarium on the kernels or maize cobs determines the increase of the amounts of mycotoxins such as Deoxynivalenol, Zearalenone, and Fumonisin, particularly dangerous for human and animal health (Wilson et al., 1980, Smith et al. for 2012). The ability of different species to produce different types of secondary metabolites, combined with their ability to coexist on the same host and/or occur in quick succession have allowed them to become invincible weapons against many plants (Baayen et al., 2000).

In Europe no fungicide for control of infection has been released. Maize that has been modified to have a Bt (Bacillus thuringiensis) endotoxin was reported to reduce the contamination with Fusarium spp. and the resultant mycotoxins in maize grain indirectly through protection of the plants against insect damage. However, Magg et al. (2002) and Papst et al. (2005) observed reduced concentration only of some mycotoxins but not of others. Breeding and growing resistant maize varieties is the best alternative to reduce yield loss and mycotoxin contamination (Bolduan, 2008).

\section{MATERIALS AND METHODS}

The experiments were carried out at ARDS Turda during four years $(2012,2013,2014,2015)$. For realizing of target of paper it was organized of byfactorial experiment by type AxBxn, after block split in three replications. Factor $A=$ Infections conditions with Fusarium spp.: natural and artificial; Factor B=Hybrids:

For the testing of hybrids in conditions of artificial infection with Fusarium spp., the 8 hybrids subject of the experience have been inoculated artificially on the maize cob, with suspension of Fusarium spp. The inoculation was performed by injecting (Bush et al, 2004) a quantity of $2 \mathrm{ml}$ of suspension, during the full fertilization phenolphase, indicated by the criteria of the stigmata turning completely brown. The inoculation method is the hypodermic one (Ceapoiu and Negulescu, 1983).

The following characteristics have been analyzed: the corn cob fusariosis expressed by diseased kernels (\%); yield capacity expressed in $\mathrm{kg} / \mathrm{ha}$ with $85 \%$, d.w.; content of starch (\%), protein (\%), fat (\%); determination of mycotoxins content via the HPLCR method (Stumpf, et al, 2013).

The data obtained has been statistically calculated using POLIFACT and also correlation and regression were used.

\section{RESULTS AND DISCUSSIONS}

The climatic conditions influence the growth and development of the plants, but mostly the favorable conditions to the crop are favorable to the occurrence and development of pathogens.

In terms of temperatures recorded in the four years of the experiment, it can be seen that in 2014 the values recorded were the closest to the average temperatures over 57 years, the year being considered to be normal from in terms of heat. In 2012, compared to other years, the temperatures have been higher, as during July and August have been recorded the highest temperatures. The year has been a warm one. Year 2013 was a hot year, with the maximum temperature in August (Fig. 1). From thermal point of view, year 2015 was a hot year, with the highest temperatures recorded during the months of July, August and September.

With regard to precipitation, the four years were very different. As it can be seen (Fig. 2), in 


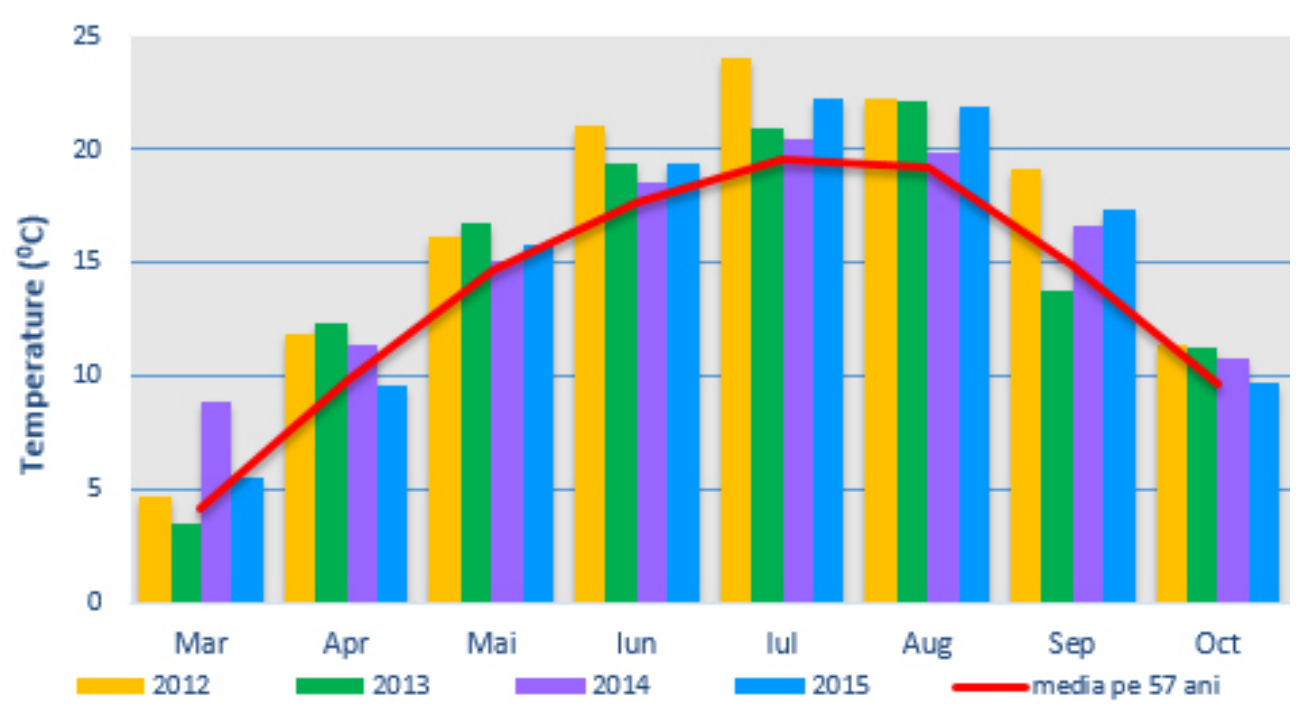

Fig. 1. The thermal regime at ARDS Turda 2012-2015

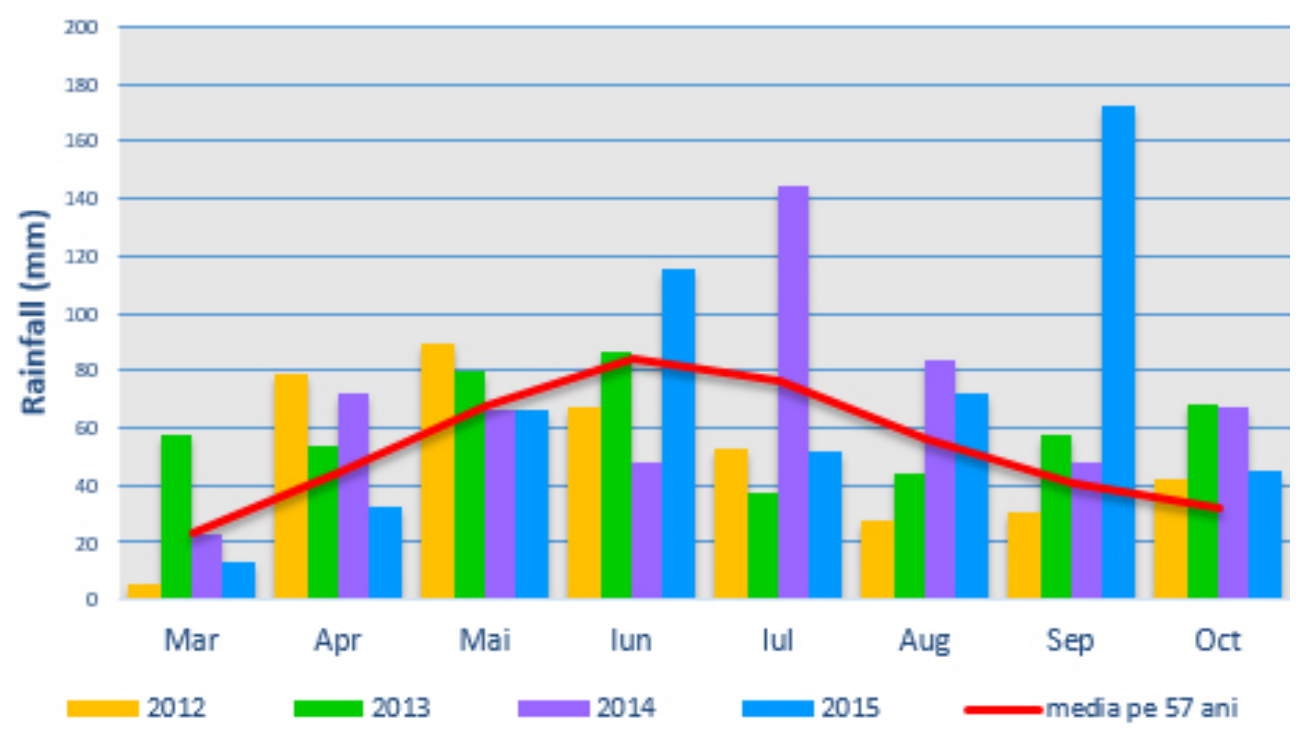

Fig. 2. The rainfall regime at ARDS Turda 2012-2015

of the most years the precipitation recorded were lower than the average of those 57 years. From the point of view of precipitations, the years of the experiment have been described as follows: year 2012 has been normal, year 2013 has been normal, year 2014 was excessively rainy and it was the most favorable for the cultivation of corn, of all the four during which the experiments tool place, year 2015 has been very rainy.

With regard to the interaction of the three factors taken within the study, regarding the degree of Fusarium spp. attack on corn cobs, it can be noted that each of them had influence on the percentage of fusariosis on the corn cob. The climatic conditions are among the most important factors that influence the emergence and spread of Fusarium species. Different climatic conditions (temperature and rainfall) influence the incidence of pathogens responsible for producing fusariosis (Ferrigo et al., 2016). The climatic conditions during the years of the experiment have influenced differently the emergence and development of the pathogen. As it can be seen in the table, the most favorable conditions for Fusarium spp. existed in 2015. 
Tab. 2. The interaction year $\mathrm{x}$ hybrid $\mathrm{x}$ infection mode on diseases maize cob

\begin{tabular}{|c|c|c|c|c|c|c|c|}
\hline No. & Factors & $\begin{array}{l}\text { The attack } \\
\text { degree } \%\end{array}$ & $\begin{array}{c}\text { The attack } \\
\text { degree } \\
\arcsin \sqrt{ } \%\end{array}$ & $\%$ to control & $\begin{array}{c}\text { The difference } \\
\text { to control }\end{array}$ & $\begin{array}{l}\text { The } \\
\text { significance of } \\
\text { the difference }\end{array}$ & Duncan Test \\
\hline \multicolumn{8}{|c|}{ Year } \\
\hline 1. & Average & 4.9 & 12.84 & 100.0 & 0.00 & Control & \\
\hline 2. & 2012 & 4.3 & 12.03 & 93.7 & -0.80 & 0 & $\mathrm{~B}$ \\
\hline 3. & 2013 & 3.2 & 10.25 & 79.9 & -2.59 & 000 & $\mathrm{~A}$ \\
\hline 4. & 2014 & 5.3 & 13.26 & 103.3 & 0.42 & - & $\mathrm{C}$ \\
\hline 5. & 2015 & 7.4 & 15.80 & 123.1 & 2.97 & $* * *$ & $\mathrm{D}$ \\
\hline \multicolumn{2}{|c|}{ LSD (p 5\%) } & \multicolumn{6}{|c|}{0.56} \\
\hline \multicolumn{2}{|c|}{ LSD (p 1\%) } & \multicolumn{6}{|c|}{0.84} \\
\hline \multicolumn{2}{|c|}{ LSD (p 0.1\%) } & \multicolumn{6}{|c|}{1.35} \\
\hline \multicolumn{8}{|c|}{ Infection method } \\
\hline 1. & Natural & 1.1 & 5.81 & 100.0 & 0.00 & Control & A \\
\hline 2. & Artificial & 11.5 & 19.86 & 342.0 & 14.06 & $* * *$ & $\mathrm{~B}$ \\
\hline \multicolumn{2}{|c|}{ LSD (p 5\%) } & \multicolumn{6}{|c|}{0.41} \\
\hline \multicolumn{2}{|c|}{ LSD (p 1\%) } & \multicolumn{6}{|c|}{0.59} \\
\hline \multicolumn{2}{|c|}{ LSD (p 0.1\%) } & \multicolumn{6}{|c|}{0.89} \\
\hline \multicolumn{8}{|c|}{ Hybrid } \\
\hline 1. & Average & 4.9 & 12.84 & 100.0 & 0.00 & Control & Mt \\
\hline 2. & Turda 145 & 4.9 & 12.78 & 99.6 & -0.06 & - & $\mathrm{B}$ \\
\hline 3. & Turda 165 & 6.5 & 14.17 & 110.4 & 1.33 & $* * *$ & $\mathrm{C}$ \\
\hline 4. & Turda 200 & 4.3 & 11.93 & 92.9 & -0.91 & 00 & A \\
\hline 5. & Turda 201 & 5.8 & 13.93 & 108.5 & 1.10 & $* * *$ & $\mathrm{C}$ \\
\hline 6. & Turda Favorit & 4.5 & 12.30 & 95.8 & -0.54 & - & $\mathrm{AB}$ \\
\hline 7. & Turda Star & 4.8 & 12.64 & 98.4 & -0.20 & - & $\mathrm{B}$ \\
\hline & $\begin{array}{c}\text { Turda Mold } \\
188 \\
\end{array}$ & 4.7 & 12.53 & 97.6 & -0.30 & - & $\mathrm{AB}$ \\
\hline 9. & Turda SU 182 & 4.6 & 12.41 & 96.7 & -0.42 & - & $\mathrm{AB}$ \\
\hline \multicolumn{5}{|c|}{ LSD (p 5\%) } & \multicolumn{3}{|l|}{0.60} \\
\hline \multicolumn{5}{|c|}{ LSD (p 1\%) } & \multicolumn{3}{|l|}{0.79} \\
\hline \multicolumn{5}{|c|}{ LSD (p 0.1\%) } & \multicolumn{3}{|l|}{1.02} \\
\hline
\end{tabular}

During this year the highest degree of attack with fusariosis has been recorded (7.4\%), the difference in comparison with the control being very positively significant. Under the climatic conditions of the year 2013 the lowest degree of attack with fusariosis on maize cob has been registered, the difference in comparison with the control being very negatively significant.

The conditions for infection have influenced the degree of infection with Fusarium spp., on the cob. As was to be expected, under artificial infection conditions, the attack degree was much higher $(11.5 \%)$, and the difference relatively to the control was very positively significant.

The hybrids subject of the study behaved differently under the attack of Fusarium spp. Of the eight hybrids used, Turda 165 and Turda 201 were most sensitive to the fusariosis attack on cob, the differences relatively to the control being very significantly positive.

At the opposite pole lies the hybrid Turda 200 with the lowest attack degree (4.3\%), the difference relatively to the average the hybrids being significantly distinctive negative. In the case 
Tab. 3. The interaction year $\mathrm{x}$ hybrid $\mathrm{x}$ infection mode on corn yield

\begin{tabular}{|c|c|c|c|c|c|c|}
\hline No. & Factors & $\begin{array}{c}\text { Yield } \\
\text { (kg/ha) }\end{array}$ & $\begin{array}{c}\% \\
\text { to control } \\
\end{array}$ & $\begin{array}{c}\text { The difference } \\
\text { to control }\end{array}$ & $\begin{array}{l}\text { The significance } \\
\text { of the difference }\end{array}$ & Duncan Test \\
\hline \multicolumn{7}{|c|}{ Year } \\
\hline 1. & Average & 7979 & 100.0 & 0.00 & Control & - \\
\hline 2. & 2012 & 7118 & 89.2 & -861 & 000 & $\mathrm{~B}$ \\
\hline 3. & 2013 & 6798 & 85.2 & -1180 & 000 & $\mathrm{~A}$ \\
\hline 4. & 2014 & 10586 & 132.7 & 2605 & $* * *$ & $\mathrm{D}$ \\
\hline 5. & 2015 & 7416 & 92.9 & -563 & 000 & $\mathrm{C}$ \\
\hline \multicolumn{3}{|c|}{ LSD (p 5\%) } & \multicolumn{4}{|c|}{213.15} \\
\hline \multicolumn{3}{|c|}{ LSD (p 1\%) } & \multicolumn{4}{|c|}{322.77} \\
\hline \multicolumn{3}{|c|}{ LSD (p 0.1\%) } & \multicolumn{4}{|c|}{518.53} \\
\hline \multicolumn{7}{|c|}{ Infection method } \\
\hline 1. & Natural & 8572 & 100.0 & 0.00 & Control & $\mathrm{B}$ \\
\hline 2. & Artificial & 7386 & 86.2 & -1186 & 000 & A \\
\hline \multicolumn{3}{|c|}{ LSD (p 5\%) } & \multicolumn{4}{|c|}{118.71} \\
\hline \multicolumn{3}{|c|}{ LSD (p 1\%) } & \multicolumn{4}{|c|}{172.67} \\
\hline \multicolumn{3}{|c|}{ LSD (p 0.1\%) } & \multicolumn{4}{|c|}{259.01} \\
\hline
\end{tabular}

\begin{tabular}{|c|c|c|c|c|c|c|}
\hline \multicolumn{7}{|c|}{ Hybrid } \\
\hline 1. & Average & 7979 & 100.0 & 0.00 & Control & - \\
\hline 2. & Turda 145 & 7695 & 96.4 & -284 & 00 & $\mathrm{C}$ \\
\hline 3. & Turda 165 & 7429 & 93.1 & -550 & 000 & $\mathrm{~B}$ \\
\hline 4. & Turda 200 & 7148 & 89.6 & -831 & 000 & $\mathrm{~A}$ \\
\hline 5. & Turda 201 & 7677 & 96.2 & -302 & 000 & $\mathrm{C}$ \\
\hline 6. & Turda Favorit & 9570 & 119.9 & 1591 & $* * *$ & $E$ \\
\hline 7. & Turda Star & 8820 & 110.5 & 841 & $* * *$ & $\mathrm{~F}$ \\
\hline & Turda Mold 188 & 7258 & 91.0 & -721 & 000 & $\mathrm{AB}$ \\
\hline 9. & Turda SU 182 & 8236 & 103.2 & 257 & $* *$ & $\mathrm{D}$ \\
\hline \multicolumn{3}{|c|}{ LSD (p 5\%) } & \multicolumn{4}{|c|}{172.86} \\
\hline \multicolumn{3}{|c|}{ LSD (p 1\%) } & \multicolumn{4}{|c|}{229.08} \\
\hline \multicolumn{3}{|c|}{ LSD (p 0.1\%) } & \multicolumn{4}{|c|}{294.91} \\
\hline
\end{tabular}

of other hybrids under study, the attack degree was equal to or smaller than the average of the hybrids, but the differences couldn't be statistically assured.

In general culture plants diseases significantly reduce the quantity and quality of the production (Bello et al., quoted by Gxasheka et al., 2015), the losses being estimated between $7-16 \%$, but in years favorable for disease, production losses may be much higher (Nagy et al., 2012).

Based on the climate conditions of the four years of the experiment, the yield obtained for the eight hybrids taken into study were very different. From the climatic point of view, the most favorable year for the culture of maize was the year 2014, this year resulting in the largest yield $(10,586$ $\mathrm{kg} / \mathrm{ha}$ ). In the other years of the experiment, the productions were lower, in all three cases the difference against the control being very significantly negative.

The yield obtained under artificial infection were much lower than those obtained in natural conditions of infection; the difference between the two methods of infection has been of approximately 1,200 kg. During the four years of the experiment, given the two different infection conditions, the most productive hybrids have been the Turda Favorit and Turda Star. The differences in 


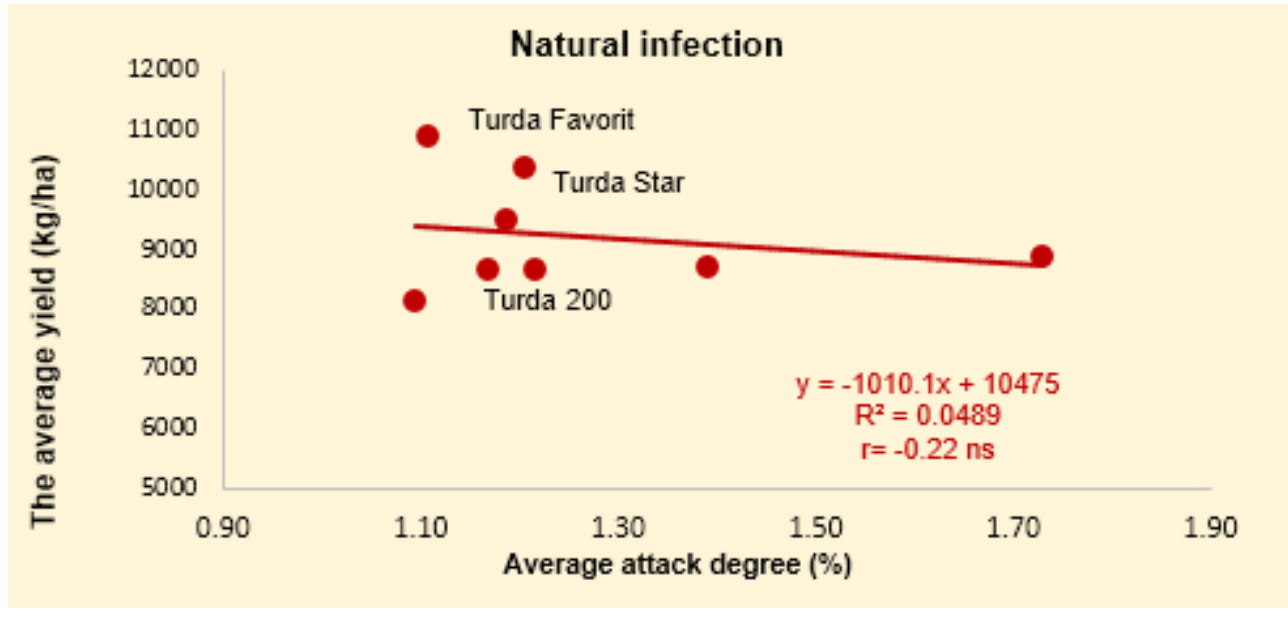

Fig. 3. The relationship between average of fusariose attack degree on corn cob and the yield average in natural infections condition (ARDS Turda 2012-2015)

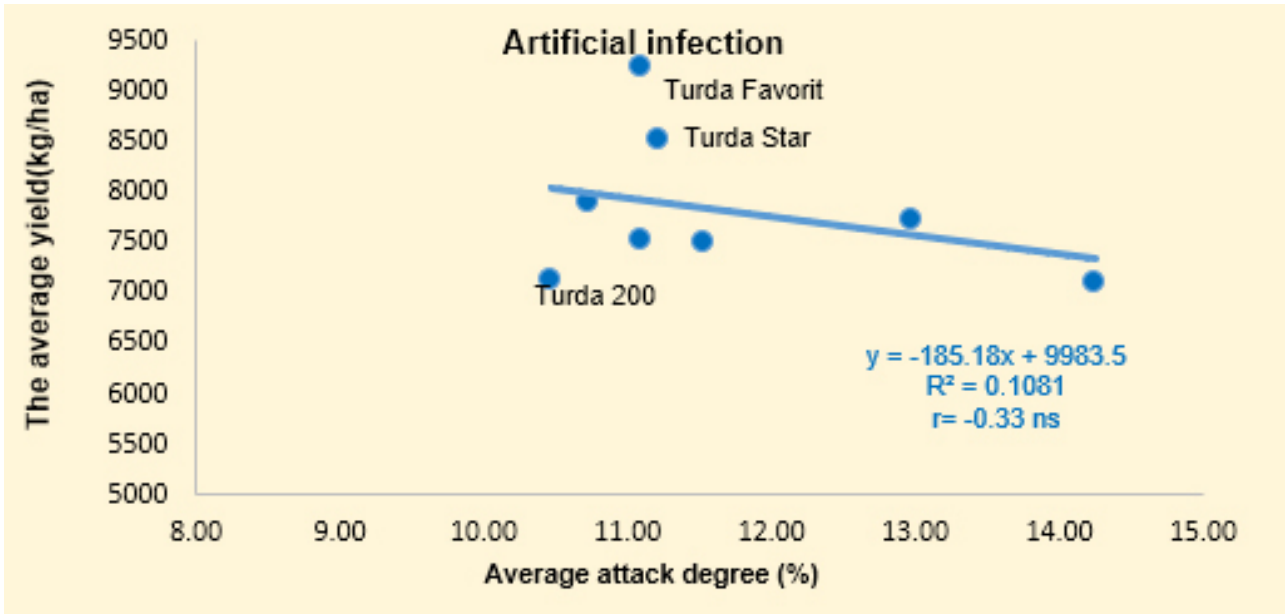

Fig. 4. The relationship between average of fusariose attack degree on corn cob and the yield average in artificial infections condition (ARDS Turda 2012-2015)

average production relatively to the average yield of the hybrids being secured statistically as very significantly positive. In terms of high the hybrid Turda SU 182 can also be noted. The productions obtained for the other hybrids has been smaller than the average yield, the differences relatively to the last have been distinctively and very significantly negative.

The negative relation between the attack degree of fusariosis on the maize cob and the yield is known. Between the two variables, a negative relation can be observed, although the value of the correlation coefficient $r$ is not statistically assured. Based on the inclination of the regression line, a negative relationship can be observed between average attack degree and yield. The hybrids Turda Favorit and Turda Star are distinguished by a high production potential and a good resistance to natural infections with Fusarium spp. exhibiting in the same time by a particular genetic progress, which is emphasized relatively to the Turda 200 hybrid.

Under artificial infection, the hybrids Turda Favorit and Turda Star are to be noted, as they had yields above average and in comparison with the other hybrids being studied. Of the two correlations it can be concluded that hybrids and Turda Favorit and Turda Star benefit from a lower attack degree of fusariosis and a higher yield potential. 


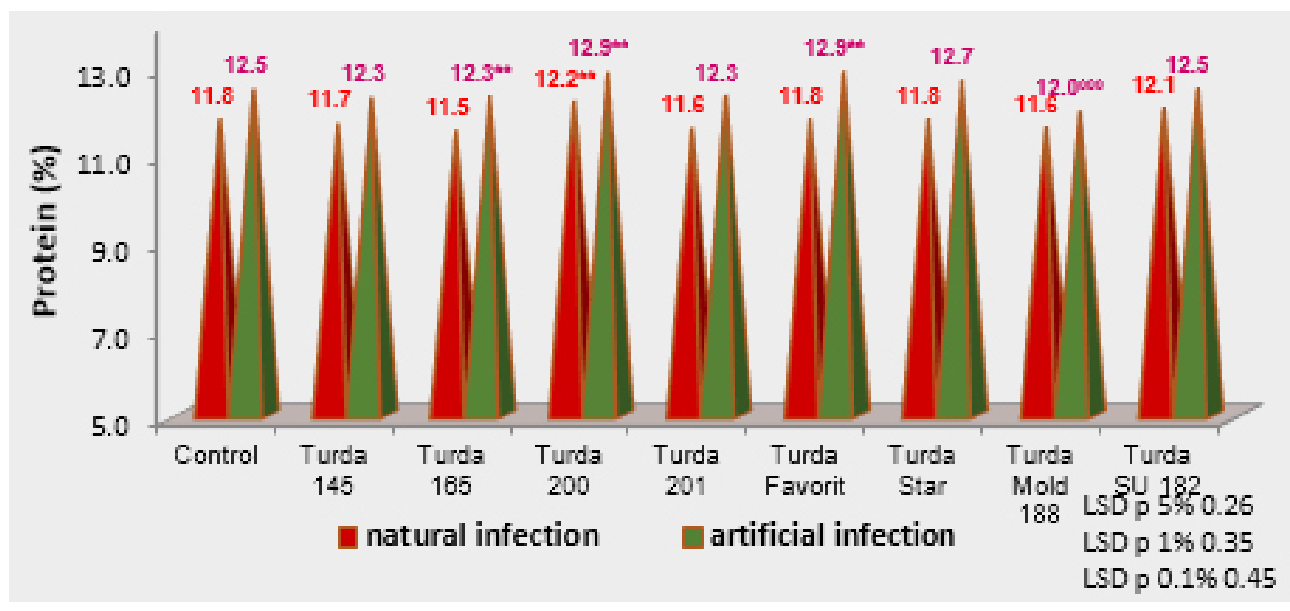

Fig. 5. The influence of Fusarium spp. infections on protein content

(ARDS Turda 2012-2015)

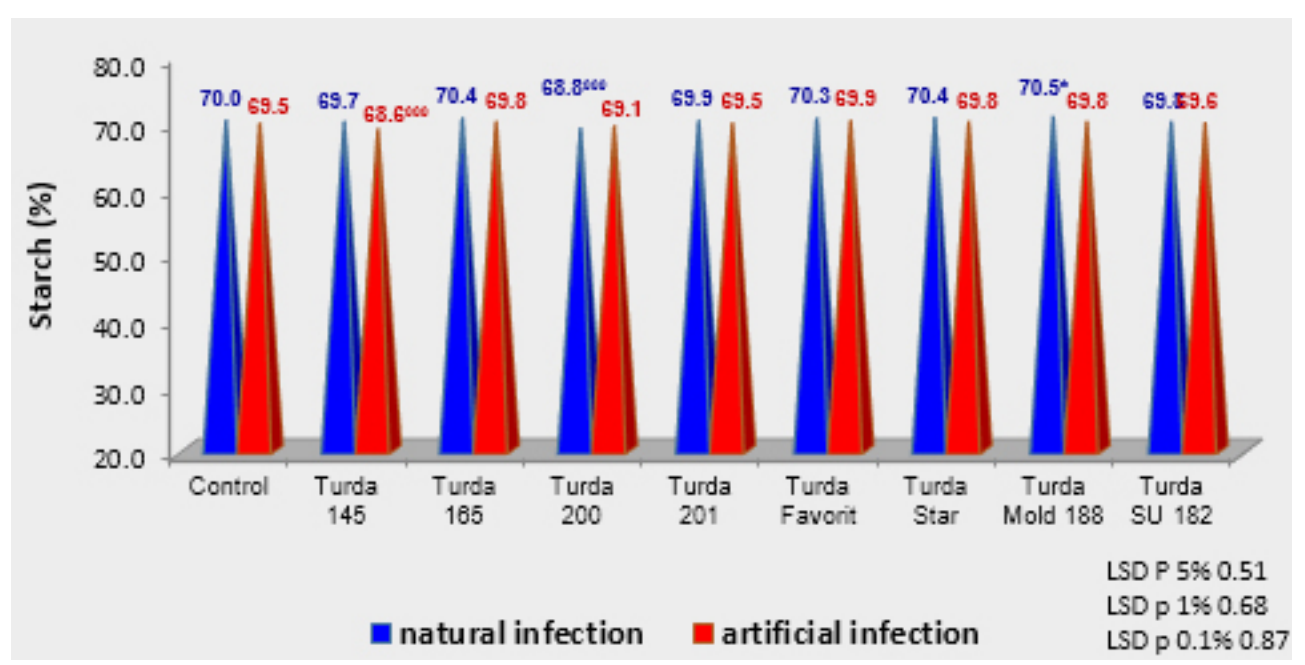

Fig. 6. The influence of Fusarium spp. infections on starch content (ARDS Turda 2012-2015)

The effect of the infection conditions with Fusarium spp. was studied also on the chemical composition of the maize kernels.

According to Nagy et al., 2009, as a result of the fusarioris infection, an increase in protein content is recorded. This perspective is apparent also in the case of our hybrids taken into study, under natural infection, where yields were higher, the amount of the protein has been low compared to the amount of protein recorded on hybrids artificially infected, which was higher. If a comparison is made between the hybrids taken into study, in terms of levels of the protein content, for both experimental variants, it can be noted that in natural conditions of infection, the Turda 200 hybrid yielded the highest percentage of protein, feature which is correlated in negative way with a reduced production of this hybrid. In terms of highest percentage of protein, in conditions of artificial infection the Turda 200 and Turda Star hybrids are to be noted. Their difference compared to the control has been very significantly positive.

There is a positive correlation between the starch content and the production, feature that can noted in Fig. 6, where the higher amount of starch is found in the variant subject to artificial infection where higher yields have been recorded. Under conditions of infection with Fusarium, once with the decrease in production a decrease in starch content in the corn caryopses, the obtained 


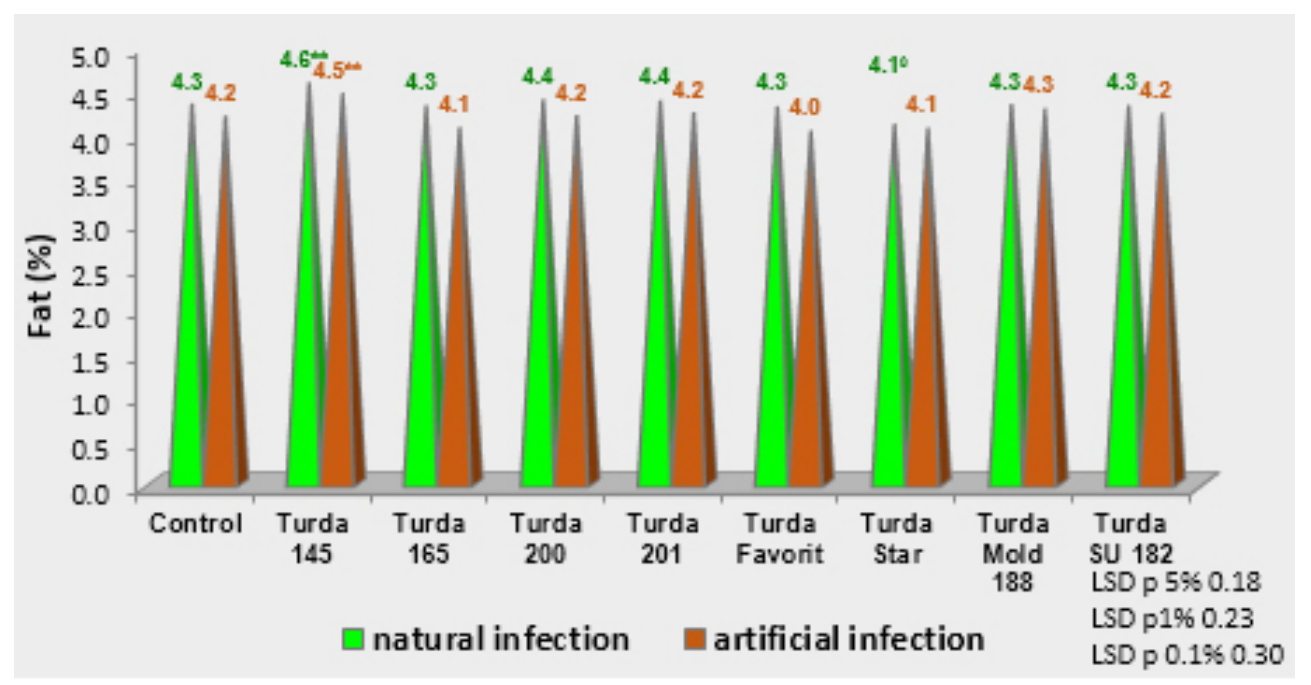

Fig. 7. The influence of Fusarium spp. infections on fat content (ARDS Turda 2012-2015)

Tab. 4. The content of mycotoxins to four corn hybrids under natural and artificial infection in 2015

\begin{tabular}{|c|c|c|c|c|}
\hline Hybrid & $\begin{array}{c}\text { Natural } \\
\text { infection }\end{array}$ & $\begin{array}{l}\text { Artificial } \\
\text { infection }\end{array}$ & $\begin{array}{r}\text { Maximum l } \\
(\mu \mathrm{g} / \mathrm{kg})\end{array}$ & \\
\hline Turda 165 & 280 & 3240 & \multirow{4}{*}{$\begin{array}{c}\text { Unprocessed maize with the } \\
\text { exception of unprocessed } \\
\text { maize intended to be } \\
\text { processed by wet milling } \\
\mathbf{4 0 0 0}\end{array}$} & \multirow{4}{*}{$\begin{array}{l}\text { Maize intended } \\
\text { for direct human } \\
\text { consumption } \\
1000\end{array}$} \\
\hline Turda 200 & 149 & 1310 & & \\
\hline Turda Star & 690 & 5630 & & \\
\hline Turda Favorit & 878 & 4280 & & \\
\hline
\end{tabular}

results are positively correlating with the research conducted by Nagy et al., 2012.

The fat content correlates positively with the obtained production. In these circumstances, it is apparent that in the case of naturally inoculated variant the protein content was lower compared with the artificially infected one, where the productions of the hybrids have been higher. Hybrid Turda 145 stands out, under conditions of natural and artificial infection, exhibiting the highest fat content, with a significant distinctly positive difference relatively to the average of the hybrids.

The rot of the cob, produced by various pathogens, including species of Fusarium, leads to a poor quality production and can result in the contamination of the kernels with mycotoxins, which poses a threat to the health of both human and animals (Logrieco et al., 2002; Munkvold, 2003 , quoted by Stumpf, et al., 2013). Fusarium species produce a large number of mycotoxins
(Deoxinevalenol, Zearalenone, Nivalenol, Fumonisin) which can be found in the corn caryopses or in products derived from there.

Because in what regards the corn hybrids created at ARDS Turda, no analyses have been performed for the Fumonisin, FB1 and FB2 content, in 2015 samples have been collected from the caryopses originating from four hybrids, that have been naturally and artificially infected with Fusarium spp.

As it can be noted in Table 4, the amount of Fumonisin detected in the samples resulting from artificial infections ranged between 150-878 $\mu \mathrm{g} /$ $\mathrm{kg}$, and the hybrid with the highest amount of mycotoxin has been the Turda Favorit. It should be noted however that in natural conditions of infection the values detected did not exceed the limits imposed by the Comission Regulation (EC) No. $1126 / 2007$.

In conditions of artificial inoculation the situation is different. Under a higher infection 
pressure with Fusarium spp., the amount of fumonisin increases; at hybrids Turda 165 and Turda 200, the values often exceed the values allowed for the maize intended for direct human consumption, but were smaller than the limits imposed for unprocessed maize with the exception of unprocessed maize intended to be processed by wet milling. The amount of fumonisin determined for the hybrids Turda Star and Turda Favorit Turda was very high; they exceeded both limits imposed for the maize. The data we have obtained correlate with those of the literature: the amount of fumonisin ranging from 68.98-336.38 $\mu \mathrm{g} / \mathrm{g}$ (Stumpf, et al, 2013), 59.68 to $1190.33 \mu \mathrm{g} / \mathrm{kg}$ (Czembor, 2015) and between 17,900 - 31,000 pg/g (Rheeder et al, 2002).

\section{CONCLUSIONS}

The hybrids subject of the study behaved differently under the attack of Fusarium spp. Turda 165 and Turda 201 were the most sensitive to the fusariosis on the cob and the Turda 200 hybrid has recorded the lowest degree of attack (4.3\%),

The rot of the cob by Fusarium spp. has significantly affected the production ability and the chemical composition of the tested corn hybrids.

The average losses of production in the four years of experimentation, regarding the studied corn hybrids studied, ranged between 3.6 and $10.4 \%$.

Under the conditions of artificial infection with Fusarium spp. has revealed a decrease in the starch and fats content and an increase in protein content compared to the variants that haven't been inoculated artificially;

The amount of fumonisin detected in the samples originating from artificial infections ranged between 149-878 ( $\mu \mathrm{g} / \mathrm{kg}) . \mathrm{In}$ natural conditions of infection the detected values did not exceed the limits imposed by the EC Regulation No $1126 / 2007$.

Data from the literature, as well as those presented previously, denote that the mode of reaction of the maize hybrids to the infection with fungi belonging to the genus Fusarium is influenced by the way of infection and by the climatic conditions. These factors affect production both in terms of quantity and quality terms.

\section{REFERENCES}

1. Baayen R.P, O’Donnell K, Bonants PJM, Cigelnik E, Kroon LPNM, Roebroeck EJA, Waalwijk C (2000). Gene genealogies and AFLP analyses in the Fusarium oxysporum complex identify monophyletic and nonmonophyletic formae speciales causing wilt and rot disease. Phytopathology 90:891-900;

2. Bolduan C, Miedanerb T, Schippracka W, Dhillona BS, Melchinger AE (2008). Genetic Variation for Resistance to Ear Rots and Mycotoxins Contamination in Early European Maize Inbred Lines, Crop Science, Vol. 49 No. 6, p. 2019-2028, doi:10.2135/cropsci2008.12.0701;

3. Bush B.J., Carson LM, Cubeta MA, Hagler WM, Payne GA (2004). Infection and fumonisin production by Fusarium verticillioides in developing maize kernels. Phytopathol, 94:88-93.

4. Ceapoiu N, Negulescu F (1983). Genetica şi ameliorarea rezistenţei la boli a plantelor, Editura A.R.S.R. Bucureşti;

5. Czembor E, Stępień L, Waśkiewicz A (2015). Effect of Environmental Factors on Fusarium Species and Associated Mycotoxins in Maize Grain Grown in Poland. PLoS ONE 10(7): e0133644.doi:10.1371/journal. pone.0133644;

6. Ferrigo D, Raiola A, Causin R (2016). Fusarium Toxins in Cereals: Occurrence, Legislation, Factors Promoting the Appearance and Their Management, Molecules, Published: 13 May 2016;

7. Gxasheka M, Wang J, Tyasi TL, Gao J (2015). Scientific understanding and effects on ear rot diseases in maize production: a review, International Journal of Soil and Crop Sciences, Vol. 3(4): pp 077-084;

8. Löffler M, Kessel B, Ouzunova M, Miedaner T (2010). Population parameters for resistance to Fusarium graminearum and Fusarium verticillioides ear rot among large sets of early, mid-late and late maturing European maize (Zea mays L.) inbred lines, Theor Appl Genet. Mar;120(5):1053-62. doi: 10.1007/s00122-009-1233-9. Epub 2009 Dec 25;

9. Magg T, Melchinger AE, Klein D, Bohn M (2002). Relationship between European corn borer resistance and concentration of mycotoxins produced by Fusarium spp. in grains of transgenic Bt maize hybrids, their isogenic counterparts, and commercial varieties. Plant Breed. 121:146-154;

10. Nagy E, Haş V, Kadar R (2006). The influence of Fusarium ear infection on the maiye yield and quality (TransilvaniaRomania). Commun. Agric. Appl.Biol. Sci., 71 (3 Pt.B): 1147-1150 (ISSN:1379-1176);

11. Nagy E, Haş V, Haş I, Suciu A, Florian V (2009). Influence of Fusarium spp. ear infection on yield and mycotoxins, in maize, AN. I.N.C.D.A. FUNDULEA. VOL. LXXVII;

12. Nagy E, Haş V, Haș I, Suciu A, Florian V. ( 2012). The influence of Fusarium ear infection on the maize yield and mycotoxin content (Transylvania-Romania), Plant Breeding and Seed Science. Volume 64, Issue, Pages 3544, ISSN (Online) 2083-599X, ISSN (Print) 1429-3862, DOI: 10.2478/v10129-011-0026-x;

13. Stumpf R, Dos Santos J, Gomes LB, Silva CN, Tessmann DJ, Ferreira FD, Machinski Junior M, Del Ponte EM (2013). 
Fusarium species and fumonisins associated with maize kernels produced in Rio Grande do Sul State for the 2008/09 and 2009/10 growing seasons, Braz J Microbiol. 2013; 44(1): 89-95;

14. Papst C, Utz HF, Melchinger AE, Eder J, Magg T, Klein D, Bohn M (2005). Mycotoxins produced by Fusarium spp. in isogenic Bt vs. non-Bt maize hybrids under European corn borer pressure. Agronomy Journal 97:219-224;

15. Smith LE, Stoltzfus RJ,Prendergast A (2012). Food chain mycotoxin exposure, gut health, and impaired growth: a conceptual framework. Advances in Nutrition: An International Review Journal 3(4): 526-531
16. Rheeder JP, Marasas WFO, Vismer HF (2002). Production of fumonisin analogs by Fusarium species. Appl. Environ. Microbiol. 68: 2101-2105.

17. Wilson DM, Windstrom NW, Mc Millian WW, Beaver RW (1980). Aflatoxinis in corn 44th, Annual Corn and Sorghum Research Conference, p. 119-143.

18. ${ }^{* * *}$ www.eur-lex.europa.eu

19. ${ }^{* * *}$ www.faostat.org

20. ${ }^{* * *}$ www.itta.com 